\title{
From Pennsylvania to Transylvania: August Ludwig Schlözer and the decentering of Enlightenment
}

\author{
Benedek M. Varga* \\ Trinity Hall, University of Cambridge \\ *Corresponding author. E-mail: bv287@cam.ac.uk
}

(Received 16 July 2019; revised 23 October 2019; accepted 27 November 2020)

This article analyzes the historical and political thinking of the eighteenth-century German historian August Ludwig Schlözer, in the context of the American War of Independence and the French Revolution. The article argues that Schlözer's disillusionment with these transformative events led him to identify the German settlers in medieval Transylvania as agents of a better Enlightenment. In doing so, Schlözer constructed the history of the Transylvanian German colony as an antithesis to American colonial endeavors, while redefining the frameworks and history of enlightened progress in both time and space. In this way, Schlözer translated the history of a marginal East-Central European region into a world-historical narrative.

\section{Introduction}

Revolutionaries in late eighteenth-century Europe generally saw America as a model of freedom and a land of opportunity. The American Revolution's achievements in dismantling the frameworks of the Old World, notably monarchy and aristocracy, heralded a new era that was soon followed by the French Revolution. Discussions of liberty, wealth and power seldom took place without referencing these watershed events, placing America at the pinnacle of the enlightened era. However, while reformers throughout Europe drew inspiration from the American constitutional system, not everyone agreed with all the principles on which it was built. One such dissenter was August Ludwig Schlözer (1735-1809), professor of history and politics at the University of Göttingen. ${ }^{1}$

By the early 1790s, Schlözer was one of the most famous, and controversial, professors in Göttingen. The son of a Lutheran pastor in the county of HohenloheKirchberg, Schlözer began his university education in Wittenberg. After completing his theology studies in 1754, he moved to Göttingen to study philology at the city's renowned university. Schlözer studied and worked in Sweden (1755-9) and then in Russia (1761-9), where he became an expert on the history of the northern

\footnotetext{
${ }^{1}$ In 1803-4, Schlözer was ennobled by Tsar Alexander I for his contributions to Russian historical scholarship. After that point, he wrote his name as von Schlözer.

(c) The Author(s), 2021. Published by Cambridge University Press. This is an Open Access article, distributed under the terms of the Creative Commons Attribution licence (http://creativecommons.org/licenses/by/4.0/), which permits unrestricted re-use, distribution, and reproduction in any medium, provided the original work is properly cited.
} 
peoples, eventually securing a professorship in Göttingen. In addition to distinguishing himself as the author of pioneering books on Russia and Scandinavia and seminal works on universal history, Schlözer was also a statistician, a professor of politics, and the editor of two immensely successful journals-the Briefwechsel (1775-82) and later the Stats-Anzeigen (1782-93)-with international reputations comparable to that of Der Spiegel today. ${ }^{2}$ Schlözer was one of the most critical and controversial observers of contemporary politics. He edited and published texts which did not envision radical social or political transformations but did criticize serfdom, religious intolerance, and the abuse of state powers in Europe. Schlözer's political commentaries were revered and even feared, not just by the public but also by princes and bishops throughout the German-speaking world. However, in 1794 his journal was finally banned due to increased pressure from state censorship in the Holy Roman Empire. ${ }^{3}$

Schlözer regularly reported the revolutionary events in America and France in his journals. A committed enlightened monarchist, he sided with Britain during the American War of Independence, which he saw as an illegal rebellion against a legitimate sovereign, and turned his back on the French Revolution after shortlived initial enthusiasm. ${ }^{4}$ As a Hanoverian subject of the English king, George III, Schlözer sincerely believed that monarchy could provide the greatest freedom to all members of a political society. ${ }^{5}$ As early as October 1789 , when the revolutionary crowd forced Louis XVI to leave Versailles for Paris, Schlözer began to doubt that the French Revolution was a battle against tyranny driven by the "greatest Enlightenment." By 1791, he became convinced that the Jacobin advocates of a republic, including the "disciples of Rousseau" and the "students of the American congress," were leading the revolution in the wrong direction, replacing monarchical principles with democratic anarchy. ${ }^{6}$

\footnotetext{
${ }^{2}$ Reinhard Lauer, "Schlözer und die Slawen," in Heinz Duchhardt and Martin Espenhorst, eds., August Ludwig (von) Schlözer in Europa (Göttingen, 2012), 23-40, at 28.

${ }^{3}$ Until that year, Schlözer and his journals had been protected from the threat of censorship during conflicts with ecclesiastical and lay institutions by the ministry in Hanover and the Holy Roman Emperor. In 1794, the Hanoverian ministry may well have believed that due to severe international tensions, it would be better if Schlözer stopped offending people. In the same year, Christoph Meiners and Ludwig Timotheus Spittler stopped publishing the Neues Göttingisches Historisches Magazin, although it is not known to have been officially banned. Friedrich Lotter, "Christoph Meiners und die Lehre von der unterschiedlichen Wertigkeit der Menschenrassen," in Harmut Boockmann and Hermann Wellenreuther, eds., Geschichtswissenschaft in Göttingen: Eine Vorlesungsreihe (Göttingen, 1987), 30-75, at 35.

${ }^{4}$ On enlightened monarchism see Hans Blom, John Christian Laursen and Luisa Simonutti, eds., Monarchisms in the Age of Enlightenment: Liberty, Patriotism, and the Common Good (Toronto, 2007); James Van Horn Melton, The Rise of the Public in Enlightenment Europe (Cambridge, 2001), 19; Melton, "From Enlightenment to Revolution: Hertzberg, Schlözer, and the Problem of Despotism in the Late Aufklärung," Central European History 12/2 (1979), 103-23, at 121-2; Martin Peters, Altes Reich und Europa: Der Historiker, Statistiker und Publizist August Ludwig (v.) Schlözer (1735-1809) (Münster, 2005), 380-94. In 2011, Peters changed his surname to Espenhorst.

${ }^{5}$ In 1714, a personal union was established between Britain and the Electorate of Hanover in the Holy Roman Empire based on the 1701 Act of Settlement. In 1782, Schlözer earned the title of Hanoverian Hofrat (a member of the Aulic Council).

${ }^{6}$ [Anon., with edits by A. L. Schlözer], "Das Neueste aus Frankreich: am Schlusse des für dieses Königreich so schrecklichen Jares 1789," Stats-Anzeigen (hereafter StA) 14 (1790), 49-56, at 51.
} 
Like many of his contemporaries, Schlözer questioned whether the events of his time pointed toward "true Enlightenment" or were instead signs of decay. In the latter case, and if the democratic ideas represented by the revolutionaries in America and the Jacobin "mob" in Paris were leading toward self-destruction and a new form of despotism, as Schlözer came to believe at an early stage of the revolution, where could the principles of a better Enlightenment be found?

This article examines Schlözer's responses to these questions and argues that he wished to challenge America's primacy as a site of higher engagement with freedom. He critically reevaluated the idea, promoted by supporters of the American War of Independence, that European colonists had built a freer and more enlightened world in North America based on republican principles. ${ }^{7}$ While many of his contemporaries focused on revolutionary events in America, whether to praise or disparage them, Schlözer drew attention to a lesser-known medieval German colonial experiment on the remote eastern frontier of the "Enlightened world," Transylvania, which he considered exemplary for its achievements in spreading civilization and building constitutionalism. ${ }^{8}$

The first German colonists had migrated from the valleys of the Rhine and Moselle rivers to Transylvania, a large eastern region of the medieval kingdom of Hungary, in the twelfth century. ${ }^{9}$ The Hungarian Crown granted them collective administrative autonomy under royal sovereignty that they cherished on their land, the Köngisboden, well into the eighteenth century. ${ }^{10}$ Together with the Hungarian nobility and the Szeklers, a Hungarian (Magyar) ethnolinguistic subgroup, the Saxons constituted the "three nations" of Transylvania. ${ }^{11}$ These nationes were not nations in the modern sense, but medieval estates which possessed different royal privileges and degrees of autonomy under the Hungarian monarchs. When the Reformation reached Transylvania, the Saxons and many Hungarian nobles eagerly embraced the new faith, which was later lauded by Schlözer, who argued that Protestants were always the most progressive and enlightened members of society across Europe. The toleration of the Protestant (Calvinist, Lutheran, Unitarian) creeds in Transylvania and the growth of the Orthodox Romanian population made early modern Transylvania a multiethnic and multi-confessional territory. ${ }^{12}$ In the sixteenth and seventeenth centuries, Transylvania witnessed

\footnotetext{
${ }^{7} \mathrm{~A}$ good example of this narrative on America, also discussed by Schlözer, is [Johann Friedrich Herel], “Die Freiheit Amerika's," Berlinische Monatsschrift 1 (1783), 386-91.

${ }^{8}$ Martin Espenhorst, "Der 'mobile' Europäer: Zur historischen Konstruktion des europäischen Menschen bei August Ludwig Schlözer," in Duchhardt and Espenhorst, August Ludwig (von) Schlözer, 197-212, at 212.

${ }^{9}$ The first medieval charters usually called the Transylvanian Germans "Teutonici" and "Flandrenses," but later in the thirteenth century this was gradually replaced by the term "Saxones." I will therefore interchangeably refer to them as Transylvanian Germans and Saxons in this text.

${ }^{10}$ In Hungarian Királyföld, in Latin Fundus Regius or Terra Saxonum, a historic region in southern Transylvania, located between the rivers Olt and Târnava Mare. It was the autonomous territory of the Saxons, established in 1224 .

${ }^{11}$ The historic origins of the Szeklers are much debated among historians. Their distinctive medieval identity and autonomy derived from their duty to defend the eastern borders of the Hungarian kingdom.

${ }^{12} \mathrm{By}$ the end of the eighteenth century, the Transylvanian population was approximately 10 percent German-speaking, 30 percent Hungarian-speaking and 60 percent Romanian-speaking. Karl A. Roider and Robert Forrest, "German Colonization in the Banat and Transylvania in the Eighteenth Century,"
} 
several political transformations: after the collapse of medieval Hungary in 1526, it became a semi-independent principality and a tributary state of the Ottoman Empire before being incorporated into the Habsburg monarchy in the late seventeenth century. ${ }^{13}$ Despite these changes, the "three nations" continued to determine Transylvanian internal affairs.

In the 1780s, however, the Holy Roman Emperor and King of Hungary, Joseph II, aimed to replace Transylvania's obsolete administrative structures with a more centralized and bureaucratized system, abolishing the medieval patchwork of privileges and autonomies. Transylvanian Saxon intellectuals saw these changes as a serious threat to their existence and feared losing their autonomy. In the 1790s, they wrote to Schlözer in Göttingen and asked him to write an account of their history and make a case for their historic rights. Schlözer maintained correspondence with a former student at Göttingen, Pastor Johann Filtsch from Hermannstadt (Nagyszeben, now Sibiu, Romania). It was Filtsch who later organized a collection of materials to be sent to Germany. ${ }^{14}$ Schlözer construed a letter which he received in 1793 from the mayor of Hermannstadt, Friedrich von Rosenfeld, as a formal commission to undertake the work.

In the three-volume Kritische Sammlungen zur Geschichte der Deutschen in Siebenbürgen (Critical Edition of the Data on the History of Germans in Transylvania) published in Göttingen between 1795 and 1797, Schlözer vigorously defended the Transylvanian Germans' medieval liberties, while enumerating their historical achievements in the region. ${ }^{15}$ This book, which incited controversies in Transylvanian intellectual circles right after its publication, touched upon many of the topics that preoccupied Schlözer throughout his life: universal history, colonization, political theory, and constitutionalism. Consequently, the Kritische Sammlungen has already drawn scholarly interest. It has been interpreted as a book in which Schlözer supported the emergence of free civic associations and pleaded for the reform of the Holy Roman Empire. ${ }^{16}$ It has also been analyzed as an important contribution to eighteenth-century debates on the historic origins and genesis of Transylvania's "nations." ${ }^{17}$ However, few attempts have been made

in Charles Ingrao and Franz A. J. Szabo, eds., Germans and the East (West-Lafayette, IN, 2008), 89-104, at 95; István Keul, Early Modern Religious Communities in East-Central Europe: Ethnic Diversity, Denominational Plurality, and Corporative Politics in the Principality of Transylvania (1526-1691) (Leiden, 2009), 15-28; R. J. W. Evans, "The Transylvanian Saxons: A German Diaspora," in Evans, Austria, Hungary, and the Habsburgs: Essays on Central Europe c. 1683-1867 (Oxford, 2006), 209-27.

${ }^{13}$ Teréz Oborni, "Between Vienna and Constantinople: Notes on the Legal Status of the Principality of Transylvania," in Gábor Kármán and Lovro Kunčević, eds., The European Tributary States of the Ottoman Empire in the Sixteenth and Seventeenth Centuries (Leiden, 2013), 67-89.

${ }^{14}$ Annamária Biró, Nemzetek Erdélyben: August Ludwig Schlözer és Aranka György vitája (Cluj-Napoca, 2011), 159-68.

${ }^{15}$ August Ludwig Schlözer, Kritische Sammlungen zur Geschichte der Deutschen in Siebenbürgen, 3 vols. (Göttingen, 1795-7) (hereafter KS).

${ }^{16}$ Peters, Altes Reich und Europa, 412; Martin Peters, "A. L. Schlözers Kritische Sammlungen zur Geschichte der Deutschen in Siebenbürgen: Kritik und Analyse," Ural-altaische Jahrbücher: Internationale Zeitschrift für uralische und altaische Forschung, new series 16 (1999-2000), 32-55, at 53-4.

${ }^{17}$ Biró, Nemzetek Erdélyben; Annamária Biró, "Schlözer und Ungarn," in Duchhardt and Espenhorst, August Ludwig (von) Schlözer, 69-84; Borbála Zsuzsanna Török, Exploring Transylvania: Geographies of 
to examine it as a work of colonial history, even though Schlözer himself labeled it as such. The only exception is the Finnish historian, Jouko Vahtola. ${ }^{18}$ While his work is rich in detail, Vahtola does not place the Kritische Sammlungen in the context of Schlözer's wider historical and political ideas on the revolutionary period and American colonization.

In fact, Schlözer's discovery of "New Germany" in Transylvania is closely linked to the problem of colonialism in late eighteenth-century German thought. Susanne Zantop, drawing on Edward Said's Orientalism, has asserted that fictional German colonial histories and colonial imaginations, developed by German writers in the eighteenth century, played a significant role in defining the characteristics of German historical self-understanding and identity. ${ }^{19}$ According to Zantop, America loomed large in German thought and served as an "imaginary testing ground" for constructing European/German supremacy and authority over colonized others, thus triggering visions of "national identity" and renewal. ${ }^{20}$ This article will demonstrate that Schlözer's engagement with America led him to reconsider the history of medieval German settlement in Transylvania as the antithesis of America, by which he hoped to form a specifically enlightened identity for Germans. Schlözer's Kritische Sammlungen was substantially shaped not only by the more recent revolutionary events in France, but also by the colonization of America, which for him became a point of reference. Therefore I suggest that it is important to read Schlözer's history of Transylvania in the light of his contributions to the debates on the American Revolution and the role played by Germans in colonizing the New World. Approaching Schlözer's work from this angle highlights that his description of "New Germany" in Transylvania was not simply meant to illustrate Germans' ability to spread their culture. It also amounted to a rethinking of the Enlightenment by mapping out an alternative to the American colonial and constitutional enterprise in East-Central Europe.

The first volume of the Kritische Sammlungen was a collection of sources related to the history of the Transylvanian Germans. The second volume comprised twelve historical case studies which discussed examples of migration and colony formation in medieval Europe that provided legal comparisons to the German settlers' rights in Transylvania and elaborated on the history of the "barbaric peoples" the Germans encountered, namely the ancient Hungarians (i.e. the Magyars) and the Pechenegs and Cumans. The latter two were Turkic nomadic peoples whose interactions with Eastern Europe intensified from the tenth and eleventh centuries through migration and military campaigns, but whose language and culture later disappeared. The third volume was a critical commentary of a royal charter, the

Knowledge and Entangled Histories in a Multiethnic Province, 1790-1918 (Leiden, 2015), 50-51; János Poór, "August Ludwig Schlözer und seine ungarländische Korrespondenzpartner," in Alexandru Duțu, Edgar Hösch and Norbert Oellers, eds., Brief und Briefwechsel in Mittel- und Osteuropa im 18. und 19. Jahrhundert (Essen, 1989), 189-202.

${ }^{18}$ Jouko Vahtola, “August Ludwig von Schlözer ja kolonisaation historia," Historiallinen Arkisto 82 (1984), 291-319, at 310. I would like to express my gratitude to Tuuli Hakala for her help in reading this article.

${ }^{19}$ Susanne Zantop, Colonial Fantasies: Conquest, Family, and Nation in Precolonial Germany, 1770-1870 (Durham, NC, 1997), 3-7.

${ }^{20}$ Ibid., 43, original emphasis. 
Andreanum. Granted by King Andrew II of Hungary in 1224, it guaranteed privileges and liberties to the German settlers in Transylvania. In Schlözer's interpretation, the Andreanum assured local autonomy under royal protection, civic liberties, and the election of officials for fixed terms, and prevented the emergence of nobility.

Schlözer highlighted this document in a 1791 issue of the Stats-Anzeigen. Readers must have been struck by his conclusion that the German settlers in thirteenth-century Transylvania "established a genuine free state under the supervision of a king ... and gave themselves also a Constitution, which has many remarkable similarities to the new N[orth] American and French constitutions." The modern connotations of the word "Constitution" (sic!) that Schlözer applied to the Andreanum underscored the continuing relevance of the German settlers' ancient freedoms in the Age of Enlightenment. In the Kritische Sammlungen, Schlözer proudly concluded,

So it was, in fine Christianitatis [on the border of Christianity], that a new and free Germany on a small scale was founded by Germans. Rightly, and following the new usage of language, it should be called New Germany, as New England, New France and New Sweden are called. I was willing to rewrite its history with the following title:

\section{The history of the German Free State in Transylvania. ${ }^{22}$}

In these sentences, Schlözer raised several questions which will be discussed below. He compared a thirteenth-century East-Central European settlement with the more recent North American colonies and a royal charter from Transylvania with the merits of the modern and enlightened American and French constitutions of the late eighteenth century, themselves the products of protracted struggle and revolutions. By doing so, Schlözer implied that the political principles associated with these constitutions were not exclusively produced in the Atlantic world, but could also be found in East-Central Europe.

This region was often the subject of the historical construction of "otherness" within Europe in both eighteenth-century and modern historiography. Larry Wolff has demonstrated that what we now call East-Central Europe was regularly designated a semi-barbarous place, mainly by French thinkers, in contrast to the leading revolutionary centers of North America and France. ${ }^{23}$ The core paradigm

\footnotetext{
${ }^{21}$ [Anon., with edits by A. L. Schlözer], "Geschichte der Deutschen in Siebenbürgen, vom J. 1143 bis 1550; und Bestand ihrer von Josef II vernichteten, aber von Leopold II wiederhergestellten Rechte," StA 16 (1791), 468-507, at 469. Schlözer later repeated this idea in a letter sent to Pastor Filtsch in 1796: Friedrich Teutsch, "Rede zur Eröffnung der 48. Generalversammlung des Vereins für siebenbürgische Landeskunde (A. L. Schlözers Kritische Sammlung zur Geschichte der Deutschen)," Archiv des Vereins für siebenbürgische Landeskunde, new series 27 (1896), 263-330, at 309. Probably due to fear of Viennese censure, Schlözer relativized the similarity between the Andreanum and the French constitution in the Kritische Sammlungen to avoid the false suspicion that he supported democracy. KS, 1: $\mathrm{x} \mathrm{n}$.

${ }^{22} \mathrm{KS}, 2: 255$.

${ }^{23}$ Larry Wolff, Inventing Eastern Europe: The Map of Civilization on the Mind of the Enlightenment (Stanford, 1994). Hans Lemberg, however, argued that the idea of Eastern Europe was a nineteenth-century
} 
of Wolff's account was modernization theory, which sought to explain the reasons for Eastern Europe's sociocultural backwardness compared to the Western world. Behind this lay a diffusionist understanding of the Enlightenment, in which the rays of reason spread from its Western intellectual centers (eminently Paris) to the less fortunate European peripheries, which were hardly able to reproduce original ideas. $^{24}$

In recent decades, scholarship has challenged this earlier description of the Enlightenment, in turn changing conceptions of its topography. Scholars highlighted that Enlightenment dialogue and interrogation varied according to cultural and geographical contexts, leading to the suggestion of referring to enlightenments in the plural. ${ }^{25}$ Furthermore, the Enlightenment increasingly came to be understood as a varied set of communicative and cultural practices aiming at the betterment of humanity and not only the ideas of an eminent group of French philosophes. $^{26}$ The picture that emerged from these observations showed that endeavors directed at improving the social, cultural and physical environments were not at all foreign to Eastern and Central European intellectual discourses. ${ }^{27}$ These elements defied conventional regionalization and center-periphery conceptions of the Enlightenment and highlighted that a more dynamic interplay developed between different places and regions in the enlightened era. ${ }^{28}$

Schlözer's history of the Transylvanian Germans represents a different view on decentering the Enlightenment's topography. Not only did it depict the Transylvanian colony as a six-hundred-year-old center of culture and commerce, it defined Transylvania as a practical realization of "true Enlightenment" and "true freedom" in Schlözer's vision. These terms became characteristic expressions of the mid-1790s, which saw a rising tide of anti-Enlightenment criticism in Germany following the French Revolution. The debate initiated in the 1780s by J. F. Zöllner's famous question in the Berlinische Monatsschrift, Was ist Aufklärung?, was taken up again with renewed vigor, especially in the wake of revolutionary events in France in $1789 .{ }^{29}$ German intellectuals who supported

construct. Hans Lemberg, “Zur Entstehung des Osteuropabegriffs im 19. Jahrhundert vom 'Norden' zum 'Osten' Europas,” Jahrbücher für Geschichte Osteuropas 33/1 (1985), 48-91. Schlözer primarily applied a north-south divide when discussing the geography and history of Europe. Espenhorst, "Der 'mobile' Europäer," 203.

${ }^{24}$ Teodora Shek Brnardić, "Intellectual Movements and Geopolitical Regionalization: The Case of the East European Enlightenment," East Central Europe/ L'Europe du centre-est 32/1 (2005), 147-77, at 169; Brnardić, "The Enlightenment in Eastern Europe: Between Regional Typology and Particular Micro-history," European Review of History/Revue européenne d'histoire 13/3 (2006), 411-35.

${ }^{25}$ Roy Porter and Mikulás Teich, eds., The Enlightenment in National Context (Cambridge, 1981).

${ }^{26}$ John Robertson, The Case for the Enlightenment: Scotland and Naples 1680-1760 (Cambridge, 2005).

${ }^{27}$ László Kontler, “The Enlightenment in Central Europe?”, in Balázs Trencsényi and Michal Kopeček, eds., Discourses of Collective Identity in Central and Southeast Europe (1770-1945): Texts and Commentaries, vol. 1, Late Enlightenment: Emergence of the Modern "National Idea" (Budapest, 2006), 33-44.

${ }^{28}$ Richard Butterwick, Simon Davies and Gabriel Sánchez Espinosa, eds., Peripheries of the Enlightenment (Oxford, 2008); Carla Hesse, “Towards a New Topography of Enlightenment," European Review of History/Revue européenne d'histoire 13/3 (2006), 499-508.

${ }^{29}$ James Schmidt, ed., What Is Enlightenment? Eighteenth-Century Answers and Twenty-First-Century Questions (Berkeley, 1996); Joachim Whaley, “Wahre Aufklärung kann erreicht und segensreich werden': The German Enlightenment and Its Interpretation," Oxford German Studies 44/4 (2015), 428-48, at 442. 
monarchy and constitutionalism felt the need to find a middle ground between revolutionary radicalism and political orthodoxy. Responding to Immanuel Kant's historic 1784 essay published in the Berlinische Monatsschrift, they sought to highlight the differences between "wahre und falsche Aufklärung" (true and false Enlightenment); that is, between incremental, moderate reform-championed by many Göttingen professors-and the subversive, revolutionary transformations of recent years. ${ }^{30}$

Schlözer's Göttingen colleague Christoph Meiners, for example, writing in the early 1790s, refuted Rousseau's theory of cultural degeneration and enumerated the benefits of the enlightened era over previous epochs. He argued that "true Enlightenment" was the opposite of superstition, despotism, anarchy, licentiousness and religious fanaticism. He emphasized that what drew the French into revolution was a "false Enlightenment" led by irreligious "prophets of equality" (Gleichheitspropheten), causing turmoil and anarchy. ${ }^{31}$ Similar arguments were developed by other intellectuals like the Lutheran pastor and writer Andreas Riem or Kant's former student Johann Heinrich Tieftrunk. They all stressed that violence was not characteristic of "true Enlightenment," which instead instructed people to obey their rulers and monarchs to improve the conditions of their subjects. Great emphasis was placed on the eminence of "German liberties," which in the 1790s came to mean that the constitution of the Holy Roman Empire provided ample freedoms to its people and that therefore Germans might need reforms, but by no means a revolution. ${ }^{32}$ The values of this strand of Enlightenment, which can be classified as "moderate" in contrast to the "radical" democratic wing, were succinctly summarized by the motto that the jurist and writer Friedrich Karl von Moser chose for his periodical: "to light up, not to set on fire."33

\footnotetext{
${ }^{30}$ Immanuel Kant, "Answer to the Question: What Is Enlightenment?" (1784), in Schmidt, What Is Enlightenment?, 58-64. On German radicalism see Martin Mulsow, Enlightenment Underground: Radical Germany, 1680-1720 (Charlottesville and London, 2002); Maximilian Lässig, Radikale Aufklärung in Deutschland: Karl von Knoblauch, Andreas Riem und Johann Christian Schmohl (Berlin, 2020).

${ }^{31}$ Christoph Meiners, Historische Vergleichung der Sitten, und Verfassungen, der Gesetze, und Gewerbe, des Handels, und der Religion, der Wissenschaften, und Lehranstalten des Mittelalters mit denen unsers Jahrhunderts in Rücksicht auf die Vortheile, und Nachtheile der Aufklärung, 3 vols. (Hanover, 1792-94), 3: 550, 585-9; Jonathan I. Israel, The Enlightenment That Failed: Ideas, Revolution, and Democratic Defeat, 1748-1830 (Oxford, 2019), 449-53; Martin Gierl, "Christoph Meiners, Geschichte der Menschheit und Göttinger Universalgeschichte: Rasse und Nation als Politisierung der deutschen Aufklärung," in Hans Erich Bödeker, Philippe Büttgen and Michel Espagne, eds., Die Wissenschaft vom Menschen in Göttingen um 1800 (Göttingen, 2008), 419-33.

${ }^{32}$ Schlözer also stressed this idea: [anon., with edits by A. L. Schlözer], "Detmold, im Decemb. 1793," StA 18 (1793), 559-60, at 560. On the varied meanings of "German liberties" see Georg Schmidt, Wandel durch Vernunft: Deutsche Geschichte im 18. Jahrhundert (Munich, 2009), 81-5, 291-6; Schmidt, "Die Idee 'deutsche Freiheit': Eine Leitvorstellung der politischen Kultur des Alten Reiches," in Georg Schmidt, Martin van Gelderen and Christopher Snigula, eds., Kollektive Freiheitsvorstellungen im frühneuzeitlichen Europa, 1400-1850 (Frankfurt am Main, 2006), 159-89; Joachim Whaley, Germany and the Holy Roman Empire, vol. 2, The Peace of Westphalia to the Dissolution of the Reich, 1648-1806 (Oxford, 2012), 351, 600-1.

33“"Zum Leuchten, nicht zum Zünden," Friedrich Karl von Moser, ed., Neues Patriotisches Archiv für Deutschland 1 (1792), title page; Jonathan I. Israel, Democratic Enlightenment: Philosophy, Revolution, and Human Rights, 1750-1790 (Oxford, 2013), 6.
} 
When Schlözer argued that the Transylvanian German constitution, unlike many others, "was based on true freedom and possible equality," he was making a clear reference to these debates. ${ }^{34}$ Thus, by outlining the unique history of the Transylvanian German colony, Schlözer decentered the symbolic geography associated with the enlightened progress of Europe and counterbalanced the story of humanity's progress with a characteristically German and Central European element. What was at stake here was not simply adding the Germans to the history of modernity or criticizing the eighteenth-century picture of Europe. ${ }^{35}$ Rather, Schlözer reconceptualized the intellectual space of the Enlightenment and the criteria of centrality that made the recent radical revolutionary movements in America and France the core of modernity while consigning the six-hundred-year-old German settlement in Transylvania and its ancient liberties to the margins. Rejecting democratic revolutions and challenging America as the fulcrum of the enlightened era, Schlözer "discovered" the Transylvanian Germans in East-Central Europe as a people who achieved prosperity and wealth comparable to those of the American colonists while firmly maintaining their allegiance to their monarchs.

To elaborate on this in more detail, I will first examine Schlözer's endeavors to broaden the geographical reach of historical inquiries toward regions that lay beyond the immediate interest of his time. I will then show his efforts to bring Transylvania to the fore in world history. In the last two sections I will present how Schlözer reformulated Transylvania as the antithesis of the New World.

\section{Decentering history}

Putting Transylvania on equal terms with America might sound unusual, but that was not true for Schlözer, who lectured and wrote books on world history. Since the first half of the eighteenth century, the University of Göttingen, where Schlözer taught, had emerged as the center of historical and anthropological debates in the German-speaking world. Göttingen historians in this period were noted for their endeavors to study the great variety of human phenomena while investigating social and cultural contexts and seeking to base their arguments on critically examined factual evidence (hence the title of Schlözer's Kritische Sammlungen). Göttingen was also a center for research on the non-European world, with keen investigations into the anthropology, geography and history of distant cultures. ${ }^{36}$

\footnotetext{
${ }^{34} \mathrm{KS}, 1$ : viii, my italics.

${ }^{35}$ Espenhorst, "Der 'mobile' Europäer," 203.

${ }^{36}$ André de Melo Araújo, Weltgeschichte in Göttingen: Eine Studie über das spätaufklärerische universalhistorische Denken, 1756-1815 (Bielefeld, 2012); Peter Hanns Reill, The German Enlightenment and the Rise of Historicism (Berkeley, 1975); Horst Walter Blanke and Dirk Fleitscher, "Artikulation bürgerlichen Emanzipationsstrebens und der Verwissenschaftlichungsprozeß der Historie: Grundzüge der deutschen Aufklärungshistorie und die Aufklärungshistorik," in Blanke and Fleitscher, eds., Theoretiker der deutschen Aufklärungshistorie (Stuttgart and Bad Cannstatt, 1990), 19-102; Michael C. Carhart, The Science of Culture in Enlightenment Germany (Cambridge, MA, 2007); Georg Iggers, "The University of Göttingen, 1760-1800, and the Transformation of Historical Scholarship," Storia della Storiografia 2 (1982), 11-37; Martin Gierl, Geschichte als präzisierte Wissenschaft: Johann Christoph Gatterer und die Historiographie des 18. Jahrhunderts im ganzen Umfang (Stuttgart and Bad Cannstatt, 2012), 349-73; Anne Saada, "Die Universität Göttingen: Traditionen und Innovationen gelehrter Praktiken," in
} 
World history, taught by faculty including Schlözer and his colleague and competitor Johann Christoph Gatterer, was a key subject at the University of Göttingen. These historians aimed to construct a total overview of history, embracing all eras and regions and enfolding all scattered local histories into one general system. Schlözer compressed the essence of this project into the phrase "das Aggregat zum System" (casting the aggregate into a system). ${ }^{37}$ Although Schlözer believed that Europe had advanced to a higher stage of civilization than the rest of the world, he was dissatisfied with many of his contemporaries, who took little interest in the variety of historical transformations that took place beyond the European core.

From early on, Schlözer had complained that the geographical scope of "world history" (Weltgeschichte) was too narrow and one-sided, embracing only the places that were important "according to today's European state system." ${ }^{38}$ In 1768, while trying to arouse interest in his own research field of Russian history, which had previously prompted little in-depth study, Schlözer compared history to botany in terms of the need to widen its geographical reach. ${ }^{39}$ In the spirit of the Göttingen historians, Schlözer wrote that while individual landowners were interested only in the plants that grew in their fields and brought them a profit, botanists must study the plants of Mexico or Kamchatka with the same curiosity as local ones. Similarly, a general history must cover the entire earth without preference for the historian's homeland or national community. It should focus as much on the Incas in South America, or Genghis Khan in the Mongol Empire, as on the Carolingians or Louis XIV in France. ${ }^{40}$

Decentering was thus a crucial aspect of Schlözer's approach to writing history. In his book Vorstellung seiner Universal-Historie (Conception of His Universal History), Schlözer argued that a world-historical outlook drew attention "away from the blind admiration of particular parts of the earth, its particular peoples, and particular types of events," and focused instead on the whole. ${ }^{41}$ For Schlözer, this included territories, countries and episodes which were not necessarily seen as integral parts of the historical canon. ${ }^{42} \mathrm{He}$ was convinced that Northern Europe and Asia had witnessed historical transformations without which events in Southern Europe could hardly be explained. Schlözer wanted to highlight that what

Bödeker, Büttgen and Espagne, Die Wissenschaft vom Menschen, 23-46; Han F. Vermeulen, Before Boas: The Genesis of Ethnography and Ethnology in the German Enlightenment (Lincoln, NE, 2015).

${ }^{37}$ August Ludwig Schlözer, Vorstellung seiner Universal-Historie, 2 vols. (Göttingen and Gotha, 1772-3), 1: 19; Franz L. Fillafer, "A World Connecting? From the Unity of History to Global History," History and Theory 56 (2017), 3-37, at 17.

${ }^{38}$ August Ludwig Schlözer, Probe Russicher Annalen (Bremen and Göttingen, 1768), 143. Cf. Pocock's ideas on the geographical focus of the "enlightened narrative": J. G. A. Pocock, Barbarism and Religion, vol. 1, The Enlightenments of Edward Gibbon 1737-1764 (Cambridge, 1999), 111-12.

${ }^{39}$ On the influence of Carl Linnaeus's work on Schlözer see Vermehulen, Before Boas, 283-95; Peters, Altes Reich und Europa, 42; Araújo, Weltgeschichte, 156.

${ }^{40}$ Schlözer, Probe, 144.

${ }^{41}$ Schlözer, Vorstellung, 1: 32.

${ }^{42}$ Schlözer knew that it would be virtually impossible to incorporate all peoples on earth into a single comprehensive system of world history; thus he included only peoples who caused "revolutions" (i.e. transformations) in history and exerted their influence on other parts of the world. Schlözer, Vorstellung, 1: 105-6. 
might have seemed unimportant and peripheral in the eighteenth century, like the medieval history of the European "north" (Russia, Scandinavia), or of the Transylvanian Germans, might actually be more relevant than previously thought. $^{43}$

In Schlözer's view, two of the most formative forces that shaped world history were migration and colonization, which made the world more connected. In the Kritische Sammlungen, Schlözer pointed out that despite their general importance to the historical understanding of the world, colonial endeavors and the phenomenon of migration had not yet been thoroughly examined. He noted, "emigrants caused as great and usually more beneficial revolutions than conquerors; since by these wandering peoples culture, religion, virtues and freedom (and only in few cases barbarism, vice and servitude) were taken to faraway lands." 44 In Schlözer's enlightened, stadialist view of history, migration and colonization represented one of the ways in which a society could be moved to a higher stage of development. ${ }^{45}$

He further adopted Rousseau's idea of human perfectibility, which he then applied to the development of peoples. Schlözer argued that in the beginning, all human beings were herd animals, with the capacity to be fully human. ${ }^{46}$ His main argument was that a people can realize its perfectibility only with the help of another, more advanced people. ${ }^{47}$ This led him to assert that no people had emerged from its primitive state by its own power; contact with another people was always required, whether it came about through either migration, colonization, trade or conquest. Thus the Ethiopians raised the Egyptians, the Egyptians the Greeks, the Greeks the Romans, the Romans the Germans, the Germans the Hungarians, the Hungarians the Vlachs. ${ }^{48}$

Schlözer held that the history of the Transylvanian Germans fitted into a common and larger pattern of world history, in which people migrating to new places set up colonies and established connections between states and societies which

\footnotetext{
${ }^{43}$ August Ludwig Schlözer, Allgemeine Nordische Geschichte: Aus den neuesten und besten Nordischen Schriftstellern und nach eigenen Untersuchungen beschrieben, und als eine Geographische und Historische Einleitung zur richtigern Kenntniß aller Skandinavischen, Finnischen, Slavischen, Lettischen, und Sibirischen Völker, besonders in alten und mittleren Zeiten (Halle, 1771). On Schlözer and Russia see Morgan Golf-French, "The Limits of the Enlightened Narrative: Rethinking Europe in Napoleonic Germany," History of European Ideas (2020), https://doi.org/10.1080/01916599.2020.1763746, 1-17, at 3-8.

${ }^{44} \mathrm{KS}$, 1: xi.

${ }^{45}$ Vahtola, "August Ludwig von Schlözer," 301-2.

${ }^{46} \mathrm{KS}, 2: 165-6$.

${ }^{47}$ In Schlözer's thought, the fundamental characteristic of humanity was Unbestimmtheit (indeterminacy), and accordingly history was a process in which humanity moved from its naturally equal state to different conditions, be they better or worse. External conditions largely determined this development. Therefore, in an enlightened manner, he stressed the importance of education and that a more advanced people could "teach" the less advanced ones. See KS, 2: 223; Martin Peters, "Möglichkeiten und Grenzen der Rezeption Rousseaus in den deutschen Historiographien: Das Beispiel der Göttinger Professoren August Ludwig (von) Schlözer und Christoph Meiners," in Herbert Jaumann, ed., Rousseau in Deutschland: Neue Beiträge zur Erforschung seiner Rezeption (Berlin and New York, 1994), 267-89, at 281-9; Daniel Fulda, Wissenschaft aus Kunst: Die Entstehung der modernen deutschen Geschichtsschreibung 1760-1860 (Berlin and New York, 1996), 196-7.

${ }^{48} \mathrm{KS}$, 2: 166. Schlözer did not solve the logical conundrum of how the first civilized people emerged if the assistance of a foreign people was always needed to achieve civilization.
} 
determined the progress of civilization. Colonization was not simply a process performed by the great ancient cultures, or the maritime powers who established overseas empires in his time; similar processes undertaken by Germans could also be detected in marginal East-Central Europe, with equally far-reaching consequences deserving the historian's scrutiny.

\section{Making Transylvania a colony}

Interest in the history of German migration to and settlement in Transylvania was certainly not new at the end of the eighteenth century, even if Schlözer admitted that in 1791 he knew as little about the Saxons in Transylvania as he did about the Germans in Germantown, Pennsylvania or Ceylon. ${ }^{49}$ Like other scholars of his time, at the end of the seventeenth century, Gottfried Wilhelm Leibniz had sought to discover the historical origins of the Transylvanian Saxon colony. As part of his linguistic investigations, of which Schlözer was aware, Leibniz initially believed that the Transylvanian Germans were remnants of the period when Germanic tribes (Visigoths) migrated to Europe and settled in Transylvania around the third century $\mathrm{AD}$, although he later learned that they were invited by the Hungarian rulers as hospites regis (guests of the king). ${ }^{50}$

Their movement was part of a larger process whereby Hungarian kings invited settlers from Western Europe or settled nomadic peoples like the Cumans and Pechenegs, who formed communities loyal to the crown. In return for royal protection and local autonomy, whose terms were laid down in the Andreanum, discussed earlier in this article, the Saxons performed various duties, including defending the borders of the realm.

Schlözer offered a new interpretation of the history of the Transylvanian Germans by framing it as a colonial history (Coloniengeschichte). In doing so, Schlözer did not just apply a common pattern of world history to a European territory, but also created a narrative in which Transylvania and Hungary were the product of German colonial activity. Schlözer asserted that it was because of the German colonists that the "barbaric" Hungarians, who arrived in the Carpathian basin in the ninth century, had become anchored in Christian Europe rather than sharing the fate of all the other nomadic tribes who had once lived around the borders of Europe before disappearing from history.

Schlözer reevaluated the Hungarians' historical narratives about their origins and presence in Transylvania. After critically examining the accounts of venerated medieval Hungarian chronicles, he asserted that the ancient Hungarian tribes had not conquered but merely occupied the Carpathian basin in the ninth century. The "subaltern horde" of Hungarians were not valiant fighters, but simply "refugees" (Flüchtlinge) forced by other nomadic peoples to leave their Asian territories for

\footnotetext{
${ }^{49} K S, 1: \mathrm{x}$.

${ }^{50}$ Schlözer was aware of Leibniz's studies and quoted him in the Kritische Sammlungen. KS, 3: 537-8 n. 5. On Leibniz's interest in Transylvania see Michael C. Carhart, Leibniz Discovers Asia: Social Networking in the Republic of Letters (Baltimore, 2019), 30, 94-100. On early modern theories about the origins of the Transylvanian Saxons see Franz Sz. Horváth, "Der Mythos der germanischen Kontinuität in Siebenbürgen," Zeitschrift für Siebenbürgische Landeskunde 22/2 (1999), 223-32.
} 
Europe.$^{51}$ Doubting the fact that Transylvania was part of the Hungarian kingdom for 150 years before the Germans' arrival, he claimed that the Hungarian monarchs could only establish control over the territory after the Saxons had settled there. ${ }^{52}$ The savage Hungarians, he suggested, relied on the German settlers' superior knowledge and more advanced technologies to defend and cultivate Transylvania.

Schlözer claimed that it was thanks to the Germans' hard labor in the Transylvanian frontier region, which had hovered between civilization and barbarism, that it finally became an unquestionable part of Europe.$^{53}$ He asserted that the nomadic Hungarians, Cumans and Bulgars were unable to improve the region's uncultivated land, and that only the more advanced German colonists could help. ${ }^{54}$ Instead of bloody conquests or tyranny over culturally inferior indigenous peoples, the German settlers in medieval Transylvania engaged in land cultivation, handicrafts and arts, all of which the Hungarians called "slave work" at the time. ${ }^{55}$

He further argued that whereas the Saxons could prove their privileges by the Andreanum, the Hungarians could not produce a similar medieval document, and he questioned the legitimacy of their centuries-old legal status. These were not simply historical claims-they were polemical interventions into the internal politics of the "three nations" of Transylvania. When Schlözer represented the Germans as the "enlightening" colonists of the Hungarians, and when he questioned the latter's privileges, he offended the local historical self-perception characterized by the separate but equal standing of the "three nations." Schlözer depicted the people of Transylvania as the passive recipients of the culture brought by Germans. Although the Germans too became "indigenous" over time, Schlözer essentially applied colonial rhetoric to six hundred years of coexistence to highlight the historical and cultural achievements of the German community. This is what Kristin Kopp calls "discursive colonization," which "repositions a specific relationship between self and Other into colonial categories." "This colonial discourse was relevant to the general argument of the Kritische Sammlungen, which aimed to protect the Saxons' autonomy and integrity.

Schlözer feared that the Transylvanian Germans would ultimately disappear from the territory if Joseph II's administrative reforms forced them to amalgamate with other ethnicities. The concivilitas (equal rights) decree issued on 4 July 1781 suspended the Saxons' long-standing legal prerogatives in the Königsboden, allowing Hungarians and Szeklers as well as Romanians, Armenians and Greeks to buy land in Saxon territory. ${ }^{57}$ Schlözer was especially worried about this last aspect. Reflecting on contemporary conditions, he argued that with the amalgamation of these peoples, "German industry, German artisanal diligence, German refinement"

\footnotetext{
${ }^{51} K S, 2: 167-71$.

${ }^{52}$ In 1003, Saint Stephen (1000/1-38), the first king of Hungary, defeated his pagan uncle who controlled Transylvania.

${ }^{53} K S, 1: 2 ; K S, 2: 241,247,259,451-2,501 ; K S, 3: 571$.

${ }^{54} \mathrm{KS}, 2: 179-8$.

${ }^{55}$ Ibid., 235.

${ }^{56}$ Kristin Kopp, Germany's Wild East: Constructing Poland as Colonial Space (Ann Arbor, 2012), 6.

${ }^{57}$ Zsolt Trócsányi, "From Enlightenment to Reaction under Emperor Francis (1771-1830)," in László Makkai and Zoltán Szász, eds., History of Transylvania, vol. 2, From 1606 to 1830 (Boulder, 2002), 623785, at 721-3; Elke Josupeit-Neitzel, Die Reformen Josephs II. in Siebenbürgen (Munich, 1986).
} 
would be lost. ${ }^{58}$ It must be emphasized here that Schlözer saw the opportunity of civilization as open to every nation. He did not consider Germans inherently superior, nor did he believe that innate national characteristics barred any people from the possibility of reaching a higher level of culture. ${ }^{59}$

While in his journals Schlözer often criticized the outdated prerogatives of the Hungarian nobility and their reluctance to improve the conditions of the peasantry, in the Kritische Sammlungen he defended the medieval rights of the Saxons and argued against enlightened reforms. ${ }^{60}$ Schlözer thus attacked ancient privileges when he believed that they hindered the development of a state and society. In Transylvania, however, he defended the Saxons' old legal status because he saw it as the precondition for enlightened development and continuous support of the monarchy. ${ }^{61}$

It is crucial to stress that in the early 1790s, the Transylvanian Saxons had already formulated ideas similar to those outlined above to defend their medieval constitution. After the death of Joseph II, anonymous political pamphlets were circulated in Transylvania emphasizing the diligence of the Saxons, the uncivilized customs of the Hungarians, and the necessity of separating the different "nations" to maintain German civilizational achievements in Transylvania. ${ }^{62}$ What made Schlözer's text different was that it went beyond mere ethnic stereotypes and applied a comparative legal and historical colonial framework to the history of Transylvania. His narrative created and stressed distances between the "nations" of Transylvania by constructing hierarchies that even his Saxon correspondents, who commissioned the work, found risky. ${ }^{63}$

While Hungarian intellectuals mostly ignored the Saxons' political pamphlets, the book of the renowned Göttingen professor caught their attention. They were seriously offended by the fact that Schlözer had questioned the privileges of the natio Hungarica and its leading role in the process of historical development. This prompted several critical reviews, although not all of them were published or reached Schlözer. ${ }^{64}$ Reviewers were convinced that Schlözer did not fully understand the local context and had misinterpreted his sources.

\footnotetext{
${ }^{58} \mathrm{KS}, 3: 663$.

${ }^{59} \mathrm{KS}, 2: 166$.

${ }^{60}$ [Anon., with edits by A. L. Schlözer], "Vorgehabte Verschwörung in Ungern gegen den ErbKönig: eine verunglückte Nachamung der französischen Revolution," StA 15 (1790), 336-55; [anon., with edits by A. L. Schlözer], "Wilde Intoleranz der katholischen Geistlichkeit in Ungern und Siebenbürgen, noch im J. 1791!", StA 16 (1791), 385-406. Further articles on Hungary: StA 15 (1790), 191-198; StA 16 (1791), 54-72, 358372.

${ }^{61}$ Biró, Nemzetek Erdélyben, 156.

${ }^{62}$ For a detailed analysis of these pamphlets see Biró, Nemzetek Erdélyben, 61-79. On discursive othering in the Habsburg monarchy see András Vári, "The Functions of Ethnic Stereotypes in Austria and Hungary in the Early Nineteenth Century," in Nancy M. Wingfield, ed., Creating the Other: Ethnic Conflict and Nationalism in Habsburg Central Europe (New York, 2003), 39-55; Klemens Kaps, "Creating Differences for Integration: Enlightened Reforms and Civilizing Missions in the Eastern European Possessions of the Habsburg Monarchy (1750-1815)," in Damien Tricoire, ed., Enlightened Colonialism: Narratives and Imperial Politics in the Age of Reason (New York, 2017), 133-55.

${ }^{63}$ Biró, Nemzetek Erdélyben, 164.

${ }^{64}$ On the reception of the Kritische Sammlungen see Peters, “A. L. Schlözers Kritische Sammlungen,” 4050; Biró, Nemzetek Erdélyben, 201-25.
} 
The Kritische Sammlungen shows how, in the German imagination, EastCentral Europe became German colonial territory at a time when Germans did not have their own overseas colonies. Like the German intellectuals who described the Baltic region as a German colony, or Frederick the Great who compared Polish West Prussia to Canada, its Slavic inhabitants to the Iroquois, and the newly founded German settlements there to Florida, Philadelphia and Saratoga, Schlözer invented Transylvania as the locus of German colonial activity. ${ }^{65}$

Once Transylvania became a colony, it also became a central stage for historical transformations, where the German settlers who civilized the brutish savages played the leading role. This enabled Schlözer not only to invent the image of the formerly unfamiliar Transylvanian Germans as agents of civilization but also to argue that they distinguished themselves from other earlier and modern colonizers, highlighting their success in Transylvania.

\section{Unmaking the myth of America}

While Schlözer emphasized the beneficial effects of the Transylvanian German colonies on civilizational development in East-Central Europe, he had to acknowledge that migration and colonization were occasionally the causes of decadence and the loss of freedom. He was aware of the vicissitudes that colonial endeavors had caused in history. Schlözer deplored the extermination of indigenous peoples and the slave trade in America. Like his contemporaries, Johann Gottfried Herder and Garlieb Helwig Merkel, Schlözer also objected to the subjugation of the Latvians by medieval German colonists in Livonia. ${ }^{66}$ In the Kritische Sammlungen Schlözer reflected on these problems. He wrote,

Most of the emigrants, who left their homeland in great numbers, and spread throughout the entire world, do not bring us much honor ... What screaming injustices would these Germans, who were planted as colonists in the Wendic lands, Prussia, Courland and Livonia etc., not permit themselves to do? Under godless pretexts they plundered the indigenous people, made them slaves or entirely uprooted them. Others were ungrateful to the princes who invited them, virtually extracting independence from them by deceit, or in some cases by openly rebelling against them. ${ }^{67}$

This latter point could have been a reference to the American Revolutionary War and colonialism in the New World, of whose contradictions Schlözer was particularly conscious. America figured prominently in the imagination of German

\footnotetext{
${ }^{65}$ David Blackbourn, The Conquest of Nature: Water, Landscape, and the Making of Modern Germany (London, 2006), 303; Kopp, Germany's Wild East, 7-8; Ulrike Plath, Esten und Deutsche in den baltischen Provinzen Russlands: Fremdheitskonstruktionen, Lebenswelten, Kolonialphantasien 1750-1850 (Wiesbaden, 2011), 263-81.

${ }^{66}$ Christian Lübke, "Ostkolonisation, Ostsiedlung, Landesbau im Mittelalter: Der ethnische und strukturelle Wandel östlich von Elbe und Saale im Blick der Neuzeit," in Enno Bünz, ed., Ostsiedlung und Landesausbau in Sachsen: Die Kührener Urkunde von 1154 und ihr historisches Umfeld (Leipzig, 2008), $467-84$, at 469 .

${ }^{67} \mathrm{KS}$, 1: vii.
} 
thinkers in the late eighteenth century. German intellectuals' interest in American issues grew considerably from the beginning of the Revolutionary War. ${ }^{68}$ This curiosity was further heightened by the presence of Hessians on the British side of the Revolutionary War and mass migration from German territories to the New World, topics on which journals such as Minerva, the Hannoverisches Magazin, Schlözer's Briefwechsel, and later the Stats-Anzeigen regularly reported. For German political thinkers, the discussion of American liberties, especially in the 1790s, became a way to express their own hopes and frustrations about the possibility of political and religious freedom. ${ }^{69}$

Schlözer frequently published letters, reports and other data on the American colonies in his periodicals. In 1777, he wrote that without knowledge of America, no advances could be made in Europe's new historical and political sciences. ${ }^{70}$ Consequently, during the Revolutionary War, he updated his readers on military affairs and provided general information about the natural, economic and political state of the Americas. Schlözer's correspondents, including Johann Christoph Kunze, a Lutheran preacher from Pennsylvania, and Captain Johann von Hinrichs, a Hessian military officer, supplied him with the latest reports, which Schlözer then passed on to readers eager to learn about the other side of the world. In addition to publishing the letters he received, he very often commented on them, revealing his position on the matters discussed in the articles. ${ }^{71}$

For Schlözer, America was above all a source of frustration. The New World was the desired destination of German emigrants, whose departure from the German territories he believed had damaged the economy of the Reich.$^{72}$ Schlözer followed the cameralist idea that a country's well-being was not primarily based on the size of the territory or its natural resources, but on how hardworking its citizens were. Thus migration was beneficial primarily to the country which received the immigrants. ${ }^{73} \mathrm{He}$ consequently made every effort to undermine the positive picture of America, making it as unappealing as possible to Germans. Martin Espenhorst argued that the reader of Schlözer's Briefwechsel learned that the New World was

\footnotetext{
${ }^{68}$ Jonathan Israel, The Expanding Blaze: How the American Revolution Ignited the World, 1775-1848 (Princeton, 2017), 44-6; Hermann Wellenreuther, Von der Konföderation bis zum Amerikanischen Nation: Der Amerikanischen Revolution zweiter Teil 1783-1796 (Berlin, 2016), 27-39, 454-73.

${ }^{69}$ A. Gregg Roeber, “'Through a Glass, Darkly”: Changing German Ideas of American Freedom, 17761806," in David E. Barclay and Elisabeth Glaser-Schmidt, eds., Transatlantic Images and Perceptions: Germany and America since 1776 (Cambridge, 1997), 19-40, at 35.

${ }^{70}$ August Ludwig Schlözer, "Vorrede," in Schlözer, ed., Neue Erdbeschreibung von Amerika, 4 vols. (Göttingen and Leipzig, 1777), 1: iii-iv.

${ }^{71}$ Christine Braun, "Soldaten zu verkaufen? Zur Diskussion über die Subsidienpolitik deutscher Fürsten in der gebildeten deutschsprachigen Öffentlichkeit Ende des 18. Jahrhunderts," in Holger Th. Gräf, Andreas Hedwig and Annegret Wenz-Haubfleisch, eds., Die "Hessians" im Amerikanischen Unabhängigkeitskrieg (1776-1783) (Marburg, 2014), 187-202, at 193-5. Inge Auerbach, Auswanderung aus Kurhessen: Nach Osten oder Westen? (Marburg, 1993), 264-6.

${ }^{72}$ Vahtola, "August Ludwig von Schlözer," 316-317. On German emigration to America see Aaron Spencer Fogleman, Hopeful Journeys: German Immigration, Settlement, and Political Culture in Colonial America, 1717-1775 (Philadelphia, 1996), 15-35; Marianne S. Wokeck, Trade in Strangers: The Beginnings of Mass Migration to North America (University Park, 1999), 37-58.

${ }^{73}$ Vahtola, "August Ludwig von Schlözer," 303.
} 
the land not of freedom and nature, but of African slavery, German serfdom and commercial parvenus. ${ }^{74}$

An article published in a 1777 issue of the Briefwechsel gave voice to these concerns. The piece-perhaps written by Schlözer himself-lamented, "There is a New Spain, New England and New Scotland in America. New Sweden was taken by New Netherlands, just as New Netherlands and New France were destroyed by Great Britain. New Denmark got lost by itself, whereas New Germany was and remained a mere project." 75 Schlözer, who added his editorial comments to the article, did not simply regret that Germans had been unable to establish a colony in America; he deplored the false vision planted in people's minds that life was easier and better in Pennsylvania. In Schlözer's view, the result was that there were 500,000 Germans in North America who were no longer interested in Germany.

Schlözer's disillusioned ideas on America were well articulated in his comments on a poem, 'Die Freiheit Amerika's' (The Freedom of America), published in the Berlinische Monatsschrift in 1783. This short poem, written in a republican spirit by the Erfurt professor Johann Friedrich Herel, became well known in Germany. $^{76}$ Among other things, it suggested that America gave a home and land to the people who settled there. Schlözer was quick to refute this claim in his Stats-Anzeigen:

$\mathrm{N}$ [orth] America is no longer like this. No emigrant is given a piece of land, still less a house: no one should travel there with this hope! Deep in the country, on the way to California, one might be able to get land for nothing: but there are bears which maul, and savages who scalp; it is also bitterly cold there. Whatever the case, it is better to stay in Germany! ${ }^{77}$

Furthermore, Schlözer was not at all convinced that Germans were free in America. ${ }^{78}$ By analogy to Negernhandel (slave trade), Schlözer coined the term Deutschenhandel (German trade) to describe the process by which Germans gave up their freedom and left their homeland for imagined wealth. ${ }^{79}$ He thought that

\footnotetext{
${ }^{74}$ Peters, Altes Reich und Europa, 284.

${ }^{75}$ [Anon., with edits by A. L. Schlözer], "NeuDeutschland oder HanauischIndien, und D. Becher: Ein actenmäßiger Bericht von dem ehemaligen Reiche des Grafen von Hanau in Süd Amerika 1669," August Ludwig Schlözers Briefwechsel meist historischen und politischen Inhalts (hereafter Briefwechsel) 2 (1777), $237-60$, at 238 .

${ }^{76}$ Jean Moes, "Geistiger Aufbruch-Politischer Aufbruch: Die Amerikanische Revolution im Spiegel deutscher zeitgenössischer Zetischriften," in Bodo Plachta and Winfried Woesler, eds., Sturm und Drang: Geistiger Aufbruch 1770-1790 im Spiegel der Literatur (Tübingen, 1997), 265-89, at 265-8.

${ }^{77}$ [August Ludwig Schlözer], "Die Freiheit Amerika's: Eine Ode. AuszugsWeise, aus der Berlinischen MontasSchrift, Apr. 1783, S. 386. Notulas historico-politico-criticas adspersit QUIDAM," StA 4 (1783), 140-4. Schlözer's article was republished in Ernst Fraenkel, ed., Amerika im Spiegel des deutschen politischen Denkens: Äußerungen deutscher Staatsmänner und Staatsdenker über Staat und Gesellschaft in den Vereinigten Staaten von Amerika (Cologne, 1959), 62-4.

${ }^{78}$ On German conceptions of liberty in North America see A. G. Roeber, Palatines, Liberty and Property: German Lutherans in Colonial British America (Baltimore, 1993).

${ }^{79}$ [Anon., with edits by A. L. Schlözer], "Vom Deutschen-Handel in NAmerika," Briefwechsel 1 (1776), 217-26, at 217 n. Cf. Hans-Jürgen Grabbe, Vor der großen Flut: Die europäische Migration in die Vereinigten Staaten von Amerika 1783-1820 (Stuttgart, 2001), 359.
} 
the system of indenture had introduced a new form of serfdom, because the law treated the indentured like British convicts or African slaves. ${ }^{80}$

The other reason behind Schlözer's attempts to persuade Germans not to travel to the New World was America's failure to fulfill its civilizational duties. While Schlözer thought that migration and colonization were essential for the general progress of humanity, he criticized the American colonists for not spreading culture among the indigenous peoples. In 1777, Schlözer commented on Richard Hakluyt's sixteenth-century colonial vision. Hakluyt wrote that taming the barbaric peoples, bringing them into civil society, and introducing reason and true faith were the most glorious legacy a man could leave. Schlözer remarked that all these "prophecies" so far remained unfulfilled. In his view, the Europeans had not yet civilized or Christianized any of the American peoples. He wrote with bitter irony that the newcomers had disseminated only brandy and smallpox. Whereas the peoples subjugated by the Greeks and Romans had gained something from that experience, contact between the Americans and Europeans had brought nothing but losses on both sides. ${ }^{81}$

Schlözer characterized American Germans as decadent. In his periodicals they were depicted not as the representatives of Enlightened culture, but as beginning to regress into a state of savagery. One of these texts even bears the title "The Relapse of Germans in North America into Barbarism." ${ }^{82}$ He ridiculed the argument of the influential Pennsylvanian Lutheran pastor Reverend Johann Christoph Kunze, that Germany should help German colonists in America. ${ }^{83}$ Schlözer wrote, "Mr Kunze thought that all of Germany should be ashamed about their runaway countrymen in Pennsylvania, these partly poor and dissolute, partly stingy barbarians, and should therefore feel obliged to help them with money and books!" ${ }^{84} \mathrm{He}$ argued that there was no need to help the Germans in Pennsylvania. Funds collected for that purpose should instead be invested in supporting missions in the fatherland and in improving schools, especially in the countryside.

Schlözer went so far as to question whether these people should still be considered German at all: they had left their homes of their own free will and had become British subjects. ${ }^{85}$ They had even gradually lost their mother tongue, which, mixed with English, became "the Pennsylvania language," barely recognizable to either the Germans or the English. ${ }^{86}$ American colonization not only was unsuccessful in

\footnotetext{
${ }^{80}$ [Anon., with edits by A. L. Schlözer], "Deutsche Emigranten nach NAmerika. Baltimore, 8. März 1791," StA 16 (1791), 114-19, at 118.

${ }^{81}$ Richard Hakluyt [with edits by A. L. Schlözer], "Von Walter Raleigh, dem Hauptstifter der Brittischen Colonien in Amerika, 1584," Briefwechsel 2 (1777), 231-7, at 235-6 n.

${ }^{82}$ Casparus Weiberg et al. [with edits by A. L. Schlözer], "Rückfall der Deutschen in NordAmerika in die Barbarei," StA 12 (1788), 480-93.

${ }^{83}$ On Reverend Kunze see Wolfgang Splitter, Pastors, People, Politics: German Lutherans in Pennsylvania, 1740-1790 (Trier, 1998), 181-5.

${ }^{84}$ Weiberg et al., "Rückfall der Deutschen," $492-3$ n.

${ }^{85}$ Johann Christoph Kunze [with edits by A. L. Schlözer], "Von der bei den Deutschen in Philadelphia angelegten lateinischen Schule: Ein Schreiben des Hrn. Pastor Kunze, vom 16 Maj 1773," Briefwechsel 1 (1776), 206-17, at 212-13 n.

${ }^{86}$ [Anon., with edits by A. L. Schlözer], "Vermischte Briefe. Philadelphia, 7 Maj 1778," Briefwechsel 3 (1778), 259-90, at 259.
} 
bringing civilization to the indigenous peoples, but also was responsible for the loss of German language and identity. ${ }^{87}$

Schlözer held that the American colonial project not only failed in spreading civilization, but also enticed people with false promises. Instead of being the beacon of liberty, it became the graveyard of enlightened endeavors and of Germans, who lost their culture and freedom there. Schlözer thus challenged the centrality assigned to America in eighteenth-century thought. At the same time, he discovered a little New Germany at the other end of the "civilized" world and demonstrated its outstanding achievements in establishing liberty, civilization and wealth, with which he believed the German colonists there overshadowed many other colonial enterprises. ${ }^{88}$

\section{New Germany in Transylvania}

Schlözer adopted an entirely different tone when discussing the medieval history of the Transylvanian German colony. He described the Transylvanian Saxons, who had for centuries preserved their language and customs among foreign peoples, as enlightened colonists par excellence. He thought it was entirely unique in colonial history that a migrant people-despite being left alone in a wasteland under difficult circumstances for so long-not only achieved prosperity and extended their power, but even progressed "faster ... than the noble Brownists and Presbyterians in New England." 89

As frontier cultivators and educators, they not only equaled but outperformed American and other settlers in many ways. The differences were already clear in the divergent motivations of the American and Transylvanian German emigrants. The American Germans who left for Pennsylvania on crowded ships were primarily motivated by the desire to become rich in the Land of Plenty. Conversely, the Transylvanian Germans' ancestors had been invited by the Hungarian kings to strengthen their rule and to civilize the Hungarians, "the awful savages from the river Don." 90 The act of "invitation" itself signified that the Transylvanian Germans did not occupy the land by conquest. Nor were they mere adventurers, escaping hunger or crime. ${ }^{91}$ They had embarked on a civilizing mission and were dedicated to these goals from the outset.

The Germans' frontier activity in Transylvania was distinguished by the fact that they were leading merchants. Schlözer believed that trade was one of the mainsprings of human progress. ${ }^{92}$ It facilitated the exchange not only of goods, but

\footnotetext{
${ }^{87}$ On the persistence of the Pennsylvanian German language and identity see Mark L. Louden, "The Pennsylvania German Language," in Simon J. Bronner and Joshua R. Brown, eds., Pennsylvania Germans: An Interpretive Encyclopedia (Baltimore, 2017), 79-107. For Schlözer, Germanness (Deutschheit) primarily manifested in German language, customs and attire. KS, 2: 267.

${ }^{88} \mathrm{KS}, 1: 18$.

${ }^{89} \mathrm{KS}, 3: 512$ n. 1.

${ }^{90} K S, 2: 246$.

${ }^{91} \mathrm{KS}, 1$ : viii.

${ }^{92}$ August Ludwig Schlözer, Versuch einer allgemeinen Geschichte der Handlung und Seefahrt in den ältesten Zeiten (Rostock, 1761). Originally published in Swedish: Schlözer, Försök til en allmän historia om Handel och Sjöfart uti the äldsta tider (Stockholm, 1758); Wilhelm Ebel, ed., Vorlesungen über Land- und Seereisen: Gehalten von Herrn Professor Schlözer. Nach dem Kollegheft des stud. jur. E.F. Haupt (Wintersemester 1795/1796) (Göttingen, 1962).
} 
also of ideas, thus enhancing the development of distant places. Schlözer was intrigued by the internal trade links between the Saxon cities. Upon examining the strong commercial ties between them, he wrote excitedly, "Look at this! A small-scale Hansa, in New Germany." ${ }^{\text {"3 }}$ Schlözer concluded that Germans in Transylvania were

a busy people that trades and manufactures at the same time, conducts the trade of an entire kingdom alone and almost exclusively, entirely duty-free, by its desirable position, connects the Orient with the Occident ... has reached an astonishing level of culture and refinement at the end of all European culture, and collects tremendous treasures. What words of praise for free trade! ${ }^{94}$

Schlözer's positive attitude toward free trade and its beneficial effects on a country's economy is all the more curious when one considers that scholars argue that he remained a committed mercantilist. ${ }^{95}$

In the late eighteenth century, it was widely held by German intellectuals, including Immanuel Kant and Johann Gottfried Herder, that the industrious Germans were "better colonizers" than the British or the French. They described German settlers as peaceful, thrifty and hardworking colonizers who were morally superior to the greedy English and cruel Spaniards. ${ }^{96}$ While Schlözer was reluctant to praise the American Germans, he employed this stereotype in the Kritische Sammlungen to make a case for the Germans' colonial success on the eastern borders of the civilized world.

Consequently, Herder read Schlözer's work with great enjoyment. The relationship between the two men had become icy for a while after Herder published a hostile review of Schlözer's Vorstellung seiner Universal-Historie in 1772, but Herder sincerely celebrated the Kritische Sammlungen more than two decades later. ${ }^{97} \mathrm{He}$ saw it as a work which described the Germans' true national character based not on a priori deduction, but on factual historical evidence which highlighted their service to European civilizational development. ${ }^{98}$

For Schlözer, the key to the Saxons' success was their unyielding loyalty to their king, even when colonists on the other side of the world rebelled against their ruler. In the public debates during the American Revolutionary War, Schlözer opposed the idea of American independence. Influenced by Montesquieu, he believed that

\footnotetext{
${ }^{93} K S, 2: 261$.

${ }^{94} K S, 3: 681-2$.

${ }^{95}$ Peters, Altes Reich und Europa, 280; Espenhorst rejected Leonard Krieger's idea that Schlözer defended economic freedom under the influence of Adam Smith. Cf. Leonard Krieger, The German Idea of Freedom: History of a Political Tradition (Chicago and London, 1972), 27.

${ }^{96}$ Zantop, Colonial Fantasies, 93-7.

${ }^{97}$ Robert S. Leventhal, "Progression and Particularity: Herder's Critique of Schlözer’s Universal History in the Context of the Early Writings," in Wulf Köpke, ed., Johann Gottfried Herder: Language, History, and the Enlightenment (Columbia, SC, 1990), 25-46; Justin Stagl, "Rationalism and Irrationalism in Early German Ethnology: The Controversy between Schlözer and Herder, 1772/73," Anthropos 93 (1998), 521-36. I am currently working on an article which will discuss the intellectual relationship between Schlözer and Herder after their debate in 1772.

${ }^{98}$ Johann Gottfried Herder, “A. L. Schlözers Geschichte der Deutschen in Siebenbürgen, 1.,2.,3., Stück, 1795-1797," Nachrichten von gelehrten Sachen 2 (1798), 249-50.
} 
constitutional monarchy was the best form of political organization, and that the English constitution was its most advanced manifestation. ${ }^{99} \mathrm{He}$ was convinced that America's economic good fortune was the result of the wise governance of British monarchs:

All Europeans who have visited America during the present war unite in speak-
ing of the wonderful prosperity of that country, which seems to strike the eye at
a glance. This prosperity, admitted by both sides, has either begun since the
rebellion of $1774,-$ a proposition which no one, in the very nature of things,
can maintain, since a poverty-stricken people require a generation under the
wisest of governments to become prosperous,-or the accounts must have
been written at a previous period when North America was under British
rule. That rule, therefore, could not have been either oppressive or tyrannical.

Thus, in his dispute with the Huguenot writer and legal scholar Jakob Mauvillon, Schlözer maintained that the War of Independence was entirely illegitimate. ${ }^{101} \mathrm{He}$ thought that the American revolutionaries' greatest mistake was that they considered the British government a system of enslavement, whereas, in his view, pure democracy could more easily take the form of despotism. ${ }^{102}$ Generally, Schlözer thought that sovereignty was not properly defined in republics out of which the tyranny of the masses could spring. In 1783, he prognosticated that ultimately this would cause the fall of the republic in America, too. ${ }^{103}$

In terms of the relationship between the Crown and colonists, Schlözer saw a clear legal analogy between America and Transylvania. He argued that in limited monarchies, wastelands were seen as the peculium (private property) of sovereigns, who could give them to whomever they wanted. To underpin this thesis, Schlözer quoted the work of his former student, the Halle historian Matthias Christian Sprengel, who argued that England's Parliament regarded the New World as the property of the Crown. ${ }^{104}$ Schlözer saw this as analogous to the Hungarian context in which King Mathis I (1458-90) declared that the Transylvanian German colonists "ought to belong solely to our royal majesty and to nobody else."105 Embracing Hugo Grotius's idea of property, Schlözer argued that after cultivating the wasteland that the sovereign gave them, the Köngisboden in Transylvania

\footnotetext{
${ }^{99}$ Roland Ludwig, Die Rezeption der Englischen Revolution im deutschen politischen Denken und in der deutschen Historiographie im 18. und 19. Jahrhundert (Lepizig, 2003), 148; Hans-Christof Kraus, Englische Verfassung und politisches Denken im Ancien Régime: 1689 bis 1789 (Munich, 2006), 582, 588.

${ }^{100}$ William L. Stone, ed. and trans., Letters of Brunswick and Hessian Officers during the American Revolution (Albany, 1891), 249-50 n. 3. Original: Friedrich Wilhelm von Steuben [with edits by A. L. Schlözer], "Copia eines Schreibens von dem GeneralMajor von STEUBEN, an den GeheimenRat ... in Hechingen: im Lager zu NeuWindsor am NordFluß, den 4 Jul. 1779," Briefwechsel 7 (1780), 327-37, at 333 n. 2.

${ }^{101}$ Peters, Altes Reich und Europa, 281.

${ }^{102}$ Louis-Joseph de Montcalm [with edits by A. L. Schlözer], "Briefe vom J. 1757 aus Amerika, worinnen der jetzige Aufrur daselbst vorausgesagt worden," Briefwechsel 2 (1777), 197-206, at 202-3 n.

${ }^{103}$ Peters, Altes Reich und Europa, 246.

${ }^{104}$ KS, 2: 370-71 n. 3; Matthias Christian Sprengel, Geschichte der Europäer in Nordamerika (Leipzig, 1782), 229.

${ }^{105} \mathrm{KS}, 2: 370-71$ n. 3 .
} 
became an absolute property of the German colonists while the ruler kept his sovereignty over the territory and collected a yearly contribution from them. ${ }^{106}$

Interestingly, in this regard, the medieval colonization of Transylvania, in Schlözer's description, had more parallels with the early English colonization of America than with the Habsburg government's geographically closer and more recent eighteenth-century endeavors in the Banat of Temesvár, the colonized military region bordering the Ottoman Empire. ${ }^{107}$

In case of the Banat, the Habsburg government paid the costs of transporting settlers-mainly Germans-to the centrally governed and underpopulated military frontier, providing them with the necessary equipment and animals. This, according to Schlözer, had important political consequences because the settlers' financial dependence on the government determined the relationship between the state and the colonists to the disadvantage of the latter.

By contrast, the early colonists of British North America-like the Germans in Transylvania-were not given financial support. They had to do everything alone, transforming the wasteland into a profitable territory. In Schlözer's view, this initial economic independence, freedom and reliance on their own means explained why the eighteenth-century descendants of the early American colonists defied the British government. ${ }^{108}$ This attitude stood in sharp contrast to the Transylvanian Germans, who, according to Schlözer, faced harsh conditions throughout the centuries, but never used this to question the Hungarian monarchs' sovereignty over their territory. Thus Schlözer contrasted the "ungrateful North American colonists" with the perennially loyal Saxons. ${ }^{109}$ He wrote,

The eternal achievement of the British monarchs in the wastelands of the New World is the work of the more recent enlightened times. The people that the Hungarian monarch created in a wasteland of the Old World was not as numerous [as the Americans], but comparatively just as free, rich, educated, and happy; and it always remained-grateful and loyal. ${ }^{110}$

For Schlözer, the difference between America and Transylvania was that while the Western colonies represented republicanism and illegitimate power, the

\footnotetext{
${ }^{106}$ Ibid., 368 n. 1, 369 n. 2; Hugo Grotius, The Rights of War and Peace, Three Books (1625), ed. Richard Tuck (Indianapolis, 2005), Bk 2, Ch. 2, 17. "And if there be any waste or barren Land within our Dominions, that also is to be given to Strangers, at their Request, or may be lawfully possessed by them, because whatever remains uncultivated, is not to be esteemed a Property, only so far as concerns Jurisdiction, which always continues the Right of the antient People."

${ }^{107}$ Curiously, Schlözer did not refer to the eighteenth-century German migration to Transylvania. On the Habsburg colonization of the Banat see William O'Reilly, "Conceptualizing America in Early Modern Central Europe," Pennsylvania History: A Journal of Mid-Atlantic Studies 65 (1998), 101-21; O’Reilly, "Agenten, Werbung und Reisemodalitäten: Die Auswanderung ins Temescher Banat im 18. Jahrhundert," in Mathias Beer and Dittmar Dahlmann, eds., Migration nach Ost- und Südosteuropa vom 18. bis zum Beginn des 19. Jahrhunderts, Ursachen-Formen-Verlauf-Ergebnis (Stuttgart, 1999), 109-20; Stephan Steiner, Rückkehr unerwünscht: Deportationen in der Habsburgermonarchie der Frühen Neuzeit und ihr europäischer Kontext (Vienna, 2014).

${ }^{108} \mathrm{KS}$, 2: 375 n. 10.

${ }^{109} \mathrm{KS}$, 3: 513 .

${ }^{110}$ Ibid., i.
} 
Transylvanian Germans on the eastern borders of the learned world, whose medieval mission was compressed into the Latin words ad retinendam coronam ("to defend the crown"), stood for monarchy and legitimate rule.

This loyalty was also reflected in the payment of taxes, which was crucial for the progress of German colonists in Transylvania. Schlözer pointed out that the Saxons' initial yearly contribution to the treasury (five hundred silver marks) had grown to half a million florins, a sum which they now paid not as colonists, but as citizens. According to Schlözer, the cause of the American revolt was that the British government wished to treat its American subjects as rich StatsBürger (citizens) rather than as poor colonists by raising their taxes as well as their compassion toward their fellow citizens in Europe. ${ }^{111}$ Thus Schlözer implied that while the North American colonists did not want to share the fiscal burdens of the state, the Transylvanian Saxons fulfilled their civic duties rather than revolting.

The document which created the framework within which the Transylvanian Saxons could fulfil their duties toward their kings and maintain their freedom was the Andreanum, discussed earlier. Schlözer was proud to highlight that this "constitution," over six hundred years old, was not written by an assembly, as in France, nor accumulated by mere accident, as in Britain, nor obtained by intrigues, as in Poland. Instead, it emulated the original German system of imperial free cities, which the migrants took with them and applied to local circumstances in "New Germany."112

Schlözer emphasized that from the mid-eleventh century, "silent revolutions" had taken place in Europe. City charters that guaranteed municipal freedom, liberating urban communities from the system of fiefdom, had woken humanity from a thousand-year slumber. ${ }^{113}$ This spirit of liberty had been brought from the Reich to Transylvania, where it had been embodied in the Saxons' mixed constitution. In Schlözer's view, the Andreanum was based on "monarchic-democratic" principles, guaranteeing the Saxons' autonomy and equality. Besides their municipal freedom and trading rights, they could choose their own priests, appoint their judges and settle legal matters according to their customary law. On their land, the Königsboden, nobody could acquire property rights unless they were members of the Saxon nation. Their constitution had successfully prevented the formation of serfdom and nobility: it was this feature of the Andreanum that Schlözer particularly celebrated. In his eyes, an outstanding feature of New Germany was that it existed outside "feudal" structures: its burghers were free, self-governing subjects. For Schlözer, these liberties, along with the Saxons' adherence to monarchy, laid the foundations for their peaceful progress and wealth in an otherwise hostile environment.

In the wake of the American and French revolutions, Schlözer aimed to demonstrate that "a free state, a republic," like that of the Transylvanian Germans, did not necessarily exclude the possibility of having a monarch. ${ }^{114}$ Following William Robertson and Christoph Meiners, he considered cities as tools for consolidating monarchical rule, because princes could rely on them to counterbalance the

\footnotetext{
${ }^{111} \mathrm{KS}, 2: 377-8$ n. 12 .

${ }^{112}$ Ibid., 254. Schlözer emphasized that the Germans were not the inventors of the "free cities." The Italian cities provided the models that they developed further.

${ }^{113} \mathrm{KS}, 3: 555$.

${ }^{114} \mathrm{KS}, 2: 255$.
} 
nobility and the bishops. ${ }^{115}$ Schlözer thought that the Saxons' cities and their mixed constitution strengthened the position of the Hungarian monarchs, who in turn left them free to govern their internal affairs. The centuries-old continuous cooperation between the monarch and the "colonists" was the key to the prosperity of the Germans in Transylvania. Thus the "republic" of the Transylvanian Saxons distinguished itself by its ability to solve the greatest conundrum of the revolutionary era: how to avoid both monarchical and democratic tyranny, which was the essence of "true freedom" for Schlözer.

In Schlözer's political thought, the American settlers, who had also received colonial charters from the English monarchs, had passed a watershed when they broke away from their ruler and their decay was imminent. The Transylvanian Germans' success in preserving their liberty and civilizational achievements, along with their loyalty to the monarchy, created a political balance that in Schlözer's view made the Transylvanian Germans' medieval constitution exemplary "for the most enlightened nations of older and newer times" alike. ${ }^{116}$

\section{Conclusion}

Schlözer's efforts to investigate the historical transformations of regions beyond the European core led him to develop a decentered conception of world history. $\mathrm{He}$ emphasized the importance of casting light on histories which were neglected in the canon of eighteenth-century historiography. As the juxtaposition of the savage Hungarians and the more enlightened German colonists indicates, this did not mean that he formulated a kind of relativist historiography. Schlözer's aim of decentering history was more about the awareness that important historical transformations which shaped the world also took place in regions which were neglected in eighteenth-century histories. This approach led him to reinterpret the role played by the Transylvanian Germans in the history of East-Central Europe. Schlözer reconceptualized medieval Transylvania as a space of German colonization and highlighted how Germans elevated the Hungarians from savagery to civilization while establishing a truly free political system. He thereby translated the history of a marginal East-Central European region into a world-historical narrative.

In parallel with the aim of decentering world history, Schlözer also decentered the Enlightenment by challenging conceptions about its supposed center and periphery. In the Kritische Sammlungen, the Transylvanian Saxons did not just step onto the stage of world history; they became the agents of a "better" Enlightenment. Reading the Kritische Sammlungen in the light of Schlözer's

\footnotetext{
${ }^{115}$ Ibid., 223 n. 1., 253-4, 253 n. 6; William Robertson, The History of the Reign of the Emperor Charles $V$. With a View of the Progress of Society in Europe, from the Subversion of the Roman Empire to the Beginning of the Sixteenth Century (Edinburgh, 1769); Christoph Meiners, Geschichte der Ungleichheit der Stände unter den vornehmsten europäischen Völkern (Hanover, 1792). On the German translations of Robertson's works and on the Scottish Enlightenment in Germany see László Kontler, Translations, Histories, Enlightenments: William Robertson in Germany, 1760-1795 (New York, 2014); Norbert Waszek, "Die Schottische Aufklärung in der Göttinger Wissenschaft vom Menschen," in Bödeker, Büttgen and Espagne, Die Wissenschaft vom Menschen in Göttingen, 125-49; Fania Oz-Salzberger, Translating the Enlightenment: Scottish Civic Discourse in Eighteenth-Century Germany (Oxford, 1995).

${ }^{116} \mathrm{KS}, 1: 3$.
} 
ideas about American colonization reveals that he developed the image of Transylvania as a German-built alternative to America. In Schlözer's eyes, Transylvania realized a potential that the New World had all but lost. He saw the recent democratic revolution in America as decadent and as the abuse of the freedoms that the English monarchs granted to the American colonists. By contrast, the centuries-old balanced constitution of the Transylvanian Germans secured monarchical rule along with their liberty and wealth, thereby achieving "the final goal of a good constitution," to make a people "happy and numerous."

Schlözer defended the ancient rights and historic status of the Transylvanian Germans against eighteenth-century reforms by depicting them as carriers of enlightened political and cultural values. He thereby changed Transylvania's place in the philosophical geography of the Enlightenment. It was no longer the marginal territory of half-enlightened people but was reinterpreted as the keeper of constitutional principles that could be considered exemplary even in the eighteenth century. For Schlözer, it was not Pennsylvania but Transylvania from which modern Germans-who tried to position themselves between revolution and conservative reaction-should draw inspiration for a balanced political order. In the decentered space of the Enlightenment, the formerly lesser-known Transylvanian German colony emerged as a rival to the revolutionary world and as the bulwark of "true Enlightenment."

Thus the Kritische Sammlungen transcended the spatial and chronological boundaries of enlightened historical narratives. In Schlözer's vision of Enlightenment, the "silent revolution" had begun in the eleventh century with the emergence of free cities. The spirit of this revolution had been imported from German territories to Transylvania and kept alive there even when it was extinguished in other parts of Europe and the wider world. Schlözer also conveyed the idea that the principles on which a truly free political constitution could be built were not exclusively or necessarily the product of recent times which were contaminated by "despotic" democratic ideas that he regarded as erroneous. Instead, he advocated turning to history to find exemplary cases of the practical implementation of successful political principles.

More importantly, Schlözer demonstrated that Germans had historic links with political practices which could realize prosperity, viable equality and freedom. They did not need to seek ideas in England, America or France to find inspiration about how to build an enlightened and free political system; instead they had merely to investigate their own history. Schlözer made the enlightened principles of politics intrinsic to the history of the Germans and regarded them as something local and rooted and not a foreign product. Schlözer's Transylvanian colonial narrative was not simply a contribution to establishing a German national character. Rather, it created a characteristically enlightened German identity.

After the American War of Independence and the French Revolution, Schlözer looked for evidence and proof that it was possible for the aims of the Enlightenment-which had failed in the colonies of the New World and on the streets of Paris-to be established in political communities and put into practice. If there was hope for finding "true freedom" in the revolutionary era, Schlözer was searching for it at the "eastern end of civilized Europe", not in the Atlantic world. 
Acknowledgments. I am grateful to William O’Reilly, Joachim Whaley, László Kontler, Avi Lifschitz, István M. Szijártó and Philippa Carter for their insightful comments on earlier versions of this article. I also want to thank Modern Intellectual History's three anonymous reviewers and Darrin M. McMahon for their helpful suggestions.

Cite this article: Varga BM (2022). From Pennsylvania to Transylvania: August Ludwig Schlözer and the decentering of Enlightenment. Modern Intellectual History 19, 349-374. https://doi.org/10.1017/ S1479244320000591 